\title{
MATERNITY AND MYOCARDIAL FAILURE IN AFRICAN WOMEN BY
}

\author{
HAROLD SEFTEL AND MERVYN SUSSER*
}

\author{
From the Baragwanath Hospital, Johannesburg, and the Department of Social and Preventive Medicine, \\ Manchester University \\ Received January 15, 1960
}

In this paper, under the name of peri-partum myocardial failure, 23 cases of idiopathic heart failure linked with maternity are described. We appraise the nature of this link.

Priority in describing a syndrome of heart failure connected with childbearing may be given to the independent reports of Gouley et al., and of Hull and Hafkesbring, both in 1937, despite the claims made for Virchow (1870), Porak (1880), and Vaquez and Millet (1898). The majority of cases have come from the Southern states of the U.S.A., but there have been several reports from other parts of North America, from Holland and England, from China and from Brazil (Jensen, 1938; Hull and Hidden, 1938; Musser et al., 1938; von Bonsdorff, 1939; Vilter and McKee, 1943; Freeman, 1947; Melvin, 1948; Mackinnon and Mackeen, 1949; Lindeboom, 1950; Chang, 1952; Woolford, 1952; Bashour and Winchell, 1954; Marcus, 1955; Meadows, 1957; Silber and Saphir, 1957; Brigden, 1957; Rosen, 1959; Benchimol et al., 1959.) The condition has not previously been reported from Africa.

All the patients in this study were African negro women, living in and around Johannesburg: 2 were discovered in a clinic practice and 20 in Baragwanath Hospital over the last three years and one patient suffered two episodes, giving a total of 23 cases. All have been observed and followed personally in hospital, clinic, and home and examined by radiology and electrocardiograph. Their nutritional histories have been taken and they have had urine and blood tests. In order to diminish bias in the selection of follow-up material, one of us (H.S.) has made a clinical survey of all surviving patients. We have rejected a large number of similar cases because of incomplete investigation or because of complications that might have contributed to heart failure, such as puerperal sepsis, hæmorrhage, white leg, or a hint of rheumatic fever. The cases were collected over the years 1953 to 1957.

\section{EPIDEMIOLOGY}

Association between Heart Failure and Childbearing. The onset of symptoms is usually within the first ten weeks of the puerperium. More than two-thirds of our patients first fell ill at this time, but in three symptoms began in the last trimester of pregnancy, and in one as late as ten months after parturition. All those in whom the onset was late were lactating, and we have taken lactation as one criterion of a relationship with maternity in cases of peri-partum failure. Apart from the three women whose symptoms began late in pregnancy, only one was not in milk at the time of onset. The high rate for breast-feeding is normal among African women, as at 5 months 92 per cent and at 12 months 77 per cent of infants may still be suckled (Gampel, 1959).

The connection of myocardial failure with maternity is not due to chance. Patients in other series and in ours have recovered from the condition only to suffer recurrence after subsequent pregnancies (Hull and Hafkesbring, 1937; Woolford, 1952; Meadows, 1957).

\footnotetext{
* Late of Alexandra Health Centre and University Clinic, Johannesburg.
} 
In order to put this relationship beyond question we compared the time that had elapsed since parturition in our 23 cases and in 100 African women of the same age-group who were admitted consecutively to our medical wards. The controls were all non-cardiac cases and had all been previously healthy. The association of heart failure and childbearing in our cases is clearly established (Table 1, columns A and B).

\section{TABLE I}

The Association with Maternity of Three Groups of Cases

A. 23 Cases of Peri-Partum Myocardial Failure.

B. 100 Consecutive Medical Admissions of Parous Women, 15-45 years, for Non-Cardiac Causes.

C. 22 Consecutive Admissions of Women 15-45 Years Diagnosed as Idiopathic Myocardial Failure.

\begin{tabular}{|c|c|c|c|c|c|c|c|c|c|}
\hline \multicolumn{4}{|c|}{ Onset of symptoms in relation to maternity } & .. & . . & . . & A. & B. & C. \\
\hline Up to 3 months pregnant & . & . & . & . & . & . & - & 10 & - \\
\hline 4-6 months pregnant & $\cdots$ & $\cdots$ & 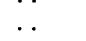 & $\ddot{0}$ & $\cdots$ & $\cdots$ & - & 3 & - \\
\hline \multirow{5}{*}{$\begin{array}{l}6 \text { months pregnant to term } \\
\text { Post-partum, 0-3 months } \\
\text { Post-partum, 4-6 months } \\
\text { Post-partum, 7-9 months } \\
\text { Post-partum, 10-12 months }\end{array}$} & & . & . & $\ldots$ & $\ldots$ & . & 3 & 2 & 2 \\
\hline & & $\ldots$ & .. & . & .. & $\ldots$ & $17^{*}$ & 7 & 13 \\
\hline & & . & . & . & . & . & 2 & 7 & 2 \\
\hline & & $\ldots$ & $\ldots$ & $\ldots$ & $\ldots$ & $\ldots$ & - & 7 & - \\
\hline & & . & . & . & .. & . & 1 & 7 & 1 \\
\hline \multicolumn{4}{|c|}{ Post-partum, 12 or more months, bu } & . & $\ldots$ & $\ldots$ & - & 3 & - \\
\hline $1-2$ years post-partum & . & $\ldots$ & .. & . & . & . & - & 13 & 1 \\
\hline \multicolumn{2}{|c|}{2 or more years post-partum } & . & . & . & $\begin{array}{l}\cdots \\
.\end{array}$ & $\cdots$ & - & 41 & 1 \\
\hline \multirow[t]{2}{*}{ Uncertain date } & . & . & . & . & . & . & - & - & 2 \\
\hline & & & & & & & 23 & 100 & 22 \\
\hline
\end{tabular}

* 8 of these occurred in the first month, 4 in the second and 5 in the third.

Incidence. In order to discover the incidence of peri-partum heart failure among all cases of idiopathic myocardial failure we examined the records of 76 African women admitted consecutively to the same medical unit with the diagnosis of idiopathic myocardial failure, and we compared them with the 100 non-cardiac control cases. We found 54 of the 76 patients with idiopathic failure to be post-menopausal. In the remaining 22 we analysed the relationship of the time of onset of heart failure and of childbearing (Table I). More than 80 per cent of the consecutive cases of idiopathic failure are related to childbearing in time of onset; only 30 per cent of other medical admissions show this relationship.

Peri-partum heart failure has been described most often in American negroes although it occurs in women of Italian, Polish, Dutch, and English stock (Gouley et al., 1937; Lindeboom, 1950; and Brigden, 1957.) Series as large as the present one have been observed only in New Orleans (Hull and Hidden, 1937), also among negroid people (Seligman, 1957).

No reliable estimate of the incidence of peri-partum failure in a representative population has been made. Woolford (1952) suggests a rate of 1 in 4000 confinements in Cincinnati, Meadows (1957) 1 in 1300 in Chicago. The two clinic cases reported here occurred among 6000 confinements. In contrast with previous samples, confinements in the clinic practice are known to be representative of confinements in the local community, but it is possible that other cases of peripartum failure occurred and were not recognized.

Age and Parity. Earlier reports show that the condition occurs throughout the child-bearing age and at all parities. The age and parity of our patients, when compared with those of the local childbearing population (Susser and Stein, 1958) were significantly greater, as shown in the following Tables (P less than 0.001).

Twin births occurred in association with 3 of the 23 episodes. An excess over the expected rate for twinning (Susser and Stein, 1958), which is here significant at the 3 per cent level, is suggested by earlier accounts. 
TABLE II

Parity compared in African Women attending Ante-Natal Clinics and In 23 Cases of Peri-Partum Myocardial Failure

\begin{tabular}{|c|c|c|c|c|c|c|c|c|}
\hline & & \multirow[t]{2}{*}{ Parity } & & \multicolumn{3}{|c|}{ Township women } & \multicolumn{2}{|c|}{$\begin{array}{l}\text { Cases with peri-partum } \\
\text { failure }\end{array}$} \\
\hline & & & & & $\%$ & Cases & $\%$ & Cases \\
\hline \multirow[t]{2}{*}{$\begin{array}{l}0 \\
1-4 \\
5+\end{array}$} & $\begin{array}{l}\ldots \\
\ldots \\
.\end{array}$ & $\begin{array}{l}\ldots \\
\ldots \\
\ldots\end{array}$ & $\begin{array}{l}\ldots \\
\cdots \\
\ldots\end{array}$ & $\begin{array}{l}\ldots \\
\ldots \\
\ldots\end{array}$ & $\begin{array}{l}18 \\
67 \\
15\end{array}$ & $\begin{array}{r}389 \\
1424 \\
321\end{array}$ & $\begin{array}{l}13 \\
43 \cdot 5 \\
43 \cdot 5\end{array}$ & $\begin{array}{r}3 \\
10 \\
10\end{array}$ \\
\hline & Total & $1 \ldots$ & . & .. & 100 & 2134 & 100 & 23 \\
\hline
\end{tabular}

TABLE III

Age Compared in African Women attending Ante-Natal Clinics and in 23 Cases of Peri-Partum Myocardial Failure

\begin{tabular}{llcccccc}
\hline \multicolumn{1}{c}{ Age } & \multicolumn{3}{c}{ Township women } & \multicolumn{2}{c}{ Cases with peri-partum } \\
& & & $\%$ & Cases & & $\%$ & Cailure \\
& & & $\%$ & & & Cases \\
\hline Under 25 years &. &. & 45 & 972 & & 13 & 3 \\
25-29 years & $\cdots$ & $\cdots$ & 33 & 703 & & 35 & 8 \\
30 years and over &.. & $\cdots$ & 32 & 459 & & 52 & 12 \\
\cline { 3 - 7 } & & & 100 & 2134 & & 100 & 23 \\
\hline
\end{tabular}

Toxamia, reported as common by some authors, occurred in few pregnancies preceding heart failure; most often this syndrome followed apparently normal pregnancies. Because the diagnosis of toxæmia had usually to be made retrospectively, doubt about its frequency persists.

\section{The Clinical Picture}

Symptoms. In most cases the onset is sub-acute or gradual; in a few, three in this series, it is acute with breathlessness and pulmonary œdema. On resuming her normal activity after confinement, the patient notices swelling of the ankles or breathlessness on effort and nocturnal cough progressing to orthopnœa. She may have bouts of paroxysmal nocturnal dyspnœa or an hæmoptysis. Some authors have described, as well as the many possible symptoms of embolism, chest pain of cardiac type and gastro-intestinal symptoms such as nausea, vomiting, and even hæmatemesis. We obtained no histories of this kind. Our patients usually sought advice within four weeks of the onset of symptoms.

Signs. None of our patients showed overt signs of malnutrition and in some it was possible to make a positive diagnosis of good nutrition, but both in Johannesburg and in the Southern States of U.S.A., the condition occurs particularly in a mal-nourished population (Hull and Hafkesbring, 1937; Gillman and Gillman, 1951).

On examination the patient is found to be in congestive cardiac failure. The pulse is rapid and regular; the extremities may or may not be cold but they are not warm, and the small or normal pulse pressure is in keeping. In 17 of our 23 cases there was a transient rise of the diastolic blood pressure between 90 and $100 \mathrm{~mm}$. $\mathrm{Hg}$. The heart was nearly always judged to be enlarged on palpation. A left ventricular thrust at the apex was felt in 18 instances and in 8 of these a right ventricular heave at the border of the sternum as well; in one patient there was only a right ventricular heave. At the apex of the heart a diastolic gallop was heard in all cases but one, a systolic murmur of variable intensity in about two-thirds, and in some a tricuspid murmur as well. 
Special Investigations. In our patients chemical and microscopic examination of the urine revealed no changes unexpected in congestive cardiac failure. Serum albumin and globulin levels were not more abnormal than for the African population in general, and leucocyte counts, hæmoglobin, urea, and electrolyte levels were all normal. The blood W.R. was negative. In four cases the sedimentation rate was high, probably due to pregnancy. Radioscopy showed cardiac enlargement in all our cases, with a cardio-thoracic ratio of 0.6 to 0.66 in 13 . The left ventricle was dominant in most and the pulsation, although variable, was usually diminished. Hilar shadowing and other findings in the lungs were normal except in three cases in which infarcts and pleural effusions occurred. Electrocardiograms were normal in only three patients. Seventeen of the remainder showed high voltage and three inverted $T$ waves over the left ventricle. There were no disturbances of conduction. When previously QRS voltage has been reported, it has been low or normal rather than high.

Course. Patients in this series have been under observation, counting only from the onset of heart failure, for periods varying from three months to $4 \frac{1}{2}$ years. The presence of ventricular hypertrophy appeared to influence the course of the disorder.

Heart Failure without Hypertrophy. Three patients had no evidence of ventricular hypertrophy and complete recovery took place within two weeks on bed rest and a salt-restricted diet (Table IV).

TABLE IV

ACUTE ReVErsible FAilure Without HyPertrophy

\begin{tabular}{|c|c|c|c|c|c|c|c|c|c|c|}
\hline \multirow{2}{*}{$\begin{array}{l}\text { Case } \\
\text { No. }\end{array}$} & \multirow{2}{*}{ Age } & \multirow{2}{*}{ Parity } & \multirow{2}{*}{$\begin{array}{l}\text { Presented } \\
\text { after } \\
\text { parturition } \\
\text { (weeks) }\end{array}$} & \multirow{2}{*}{$\begin{array}{l}\text { Lactation } \\
\text { after } \\
\text { presenta- } \\
\text { tion } \\
\text { (mth.) }\end{array}$} & \multicolumn{3}{|c|}{ Hypertrophy } & \multirow{2}{*}{$\begin{array}{c}\text { Recovered } \\
\text { C.C.F. }\end{array}$} & \multirow{2}{*}{$\begin{array}{c}\text { Recovered } \\
\text { heart } \\
\text { size }\end{array}$} & \multirow{2}{*}{$\begin{array}{c}\text { Recovery } \\
\text { maintained }= \\
\text { observation } \\
\text { period } \\
\text { (mth.) }\end{array}$} \\
\hline & & & & & $\begin{array}{l}\text { Q.R.S. } \\
\text { (mm.) }\end{array}$ & $\mid$\begin{tabular}{c|} 
T wave \\
inversion \\
(LV)
\end{tabular} & Clinical & & & \\
\hline $\begin{array}{l}1 \\
2 \\
3\end{array}$ & $\begin{array}{l}30 \\
32 \\
27\end{array}$ & $\begin{array}{l}4 \\
3 * \\
4\end{array}$ & $\begin{array}{c}2 \\
1 \\
2 \text { before }\end{array}$ & $\begin{array}{l}6 \\
\frac{1}{2} \\
0\end{array}$ & $\begin{array}{ll}\text { RV6 } & 18 \\
\text { RV5 } & 14 \\
\text { RV6 } & 16\end{array}$ & $\begin{array}{l}- \\
-\end{array}$ & $\begin{array}{l}- \\
-\end{array}$ & $\begin{array}{l}1 \\
1 \\
1\end{array}$ & $\begin{array}{l}1 \\
2 \\
1\end{array}$ & $\begin{array}{r}20 \\
5 \\
12\end{array}$ \\
\hline
\end{tabular}

* Twin pregnancy with failure.

All treated on bed rest and salt restriction alone.

The signs of congestion, gallop rhythm, and tachycardia disappeared, the blood pressure fell to normal, and the systolic murmur lessened as the heart diminished in size. All have remained well for five, twelve, and twenty months. The onset in these three cases was in late pregnancy or within two weeks of confinement. There was nothing to suggest toxæmia of pregnancy, which has been propounded as a cause of rapidly reversible post-partum heart failure (Benchimol et al., 1959).

Heart Failure with Ventricular Hypertrophy. Where there was evidence of ventricular hypertrophy, as in the remaining 20 cases, recovery was more gradual and less certain. Regression sometimes continued for as long as a year, although congestive failure usually responded within two weeks to digitalis and diuretics.

In 17 cases we based the diagnosis of hypertrophy on the quality of the cardiac impulse, radiographic enlargement, and an electrocardiogram with an R wave in leads V4, V5, and V6 of $25 \mathrm{~mm}$. or more, or an S wave in V1 greater than $15 \mathrm{~mm}$. (Wood, 1956; Levine, 1958; Hayward and Weitzman, 1958). In 3 other instances with slightly smaller $R$ and $S$ waves we took as evidence of hypertrophy a thrusting apical impulse, radiographic enlargement, and inverted $\mathrm{T}$ waves over the left ventricle.

We have classified our cases with hypertrophy into three groups according to the course of the disease.

(1) Reversion to Normal Heart Size-9 confinements (Table V). Seven patients recovered 
TABLE V

Myocardial Failure with Hypertrophied Heart Reverting to Normal Size

\begin{tabular}{|c|c|c|c|c|c|c|c|c|c|c|c|c|c|c|}
\hline \multirow{2}{*}{$\begin{array}{c}\text { Case } \\
\text { No. }\end{array}$} & \multirow{2}{*}{ Age } & \multirow{2}{*}{ Parity } & \multirow{2}{*}{ 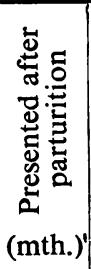 } & \multirow{2}{*}{ 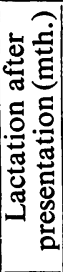 } & \multicolumn{3}{|c|}{ Hypertrophy } & \multirow{2}{*}{ 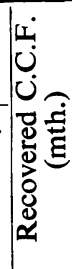 } & \multirow{2}{*}{ 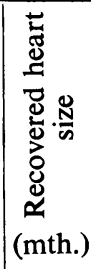 } & \multirow{2}{*}{ 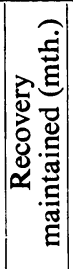 } & \multirow{2}{*}{ 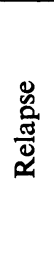 } & \multirow{2}{*}{ 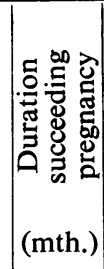 } & \multirow{2}{*}{ 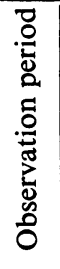 } & \multirow{2}{*}{ Comments } \\
\hline & & & & & $(\mathrm{mm})$. & \begin{tabular}{|c|}
$T$ \\
wave \\
inver- \\
sion \\
(LV)
\end{tabular} & $\mid \begin{array}{c}\text { Clini- } \\
\text { cal }\end{array}$ & & & & & & & \\
\hline 4 & 25 & 4 & -2 & 3 & RV5 26 & - & + & 1 & 3 & 2 & - & - & 6 & Death from virus hepatitis \\
\hline 5 & 22 & 3 & $2 \frac{3}{4}$ & 0 & RV6 20 & + & + & $\frac{3}{4}$ & 5 & 48 & - & FT & 53 & - \\
\hline 6 & 36 & 6 & 2 & 0 & RV4 28 & + & + & $\frac{1}{4}$ & 5 & 9 & - & $2 \frac{1}{2}^{*}$ & 14 & * Hysterotomy \\
\hline $\begin{array}{l}7 \\
8\end{array}$ & $\begin{array}{l}40 \\
19\end{array}$ & $\begin{array}{l}8 \\
1\end{array}$ & $\begin{array}{c}10 \frac{1}{2} \\
1\end{array}$ & 23 & $\begin{array}{l}\text { RV6 } 36 \\
\text { SV1 } 20\end{array}$ & $\begin{array}{l}+ \\
+\end{array}$ & $\begin{array}{l}+ \\
+\end{array}$ & $\frac{1}{4}$ & $\begin{array}{r}7 \\
11\end{array}$ & $\begin{array}{l}10 \\
20\end{array}$ & + & - & $\begin{array}{l}21 \\
31\end{array}$ & $\dagger$ Asymptomatic cardio- \\
\hline 9 & 25 & 1 & 1 & 15 & RV6 32 & + & + & $\frac{1}{2}$ & 12 & 24 & - & $2 \frac{1}{2} \ddagger$ & 36 & $\begin{array}{l}\text { † Spontaneous abortion. } \\
\text { Further F.T. } \\
\text { Pregnancy and C.C.F } \\
\text { after survey completed }\end{array}$ \\
\hline 10 & 29 & 6 & 10 & 0 & RV5 30 & - & + & $\frac{1}{4}$ & 4 & 6 & - & - & 10 & \\
\hline 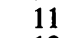 & 27 & $=$ & $2 \frac{1}{2}$ & 1 & & - & + & 4 & 13 & 12 & - & $5 \S$ & 25 & $\S$ Spontaneous abortion \\
\hline 12 & 33 & 10 & $2 \frac{1}{4}$ & 0 & RV6 30 & + & + & 4 & 5 & 10 & - & FT & 15 & $\begin{array}{l}\text { TI S.B. twins. Same patient } \\
\text { as Case 19. Recur- } \\
\text { rence and death }\end{array}$ \\
\hline
\end{tabular}

completely in 3 to 12 months. Three of these were well 9, 24* and 48 months later, but a fourth died of virus hepatitis two months after recovery. Three of the seven had further episodes of different kinds. One developed an asymptomatic increase in heart size (c.t.r. 0.52) at 20 months, and another developed heart failure after 10 months. A third had a fatal recurrence after a subsequent pregnancy. (This case is also included among the fatalities.) In the remaining two patients recovery was not quite complete. The heart size became normal again, but electrocardiographic signs of ventricular hypertrophy persisted. Despite the various complications in these 9 cases in which heart size returned to normal, only one, a woman of high age and parity, had a relapse into heart failure not connected with a subsequent pregnancy.

TABLE VI

Persistent Cardiomegaly following Myocardial Failure

\begin{tabular}{|c|c|c|c|c|c|c|c|c|c|c|c|c|c|c|}
\hline \multirow[b]{2}{*}{$\begin{array}{l}\text { Case } \\
\text { No. }\end{array}$} & \multirow[b]{2}{*}{ Age } & \multirow{2}{*}{ Parity } & \multirow{2}{*}{ 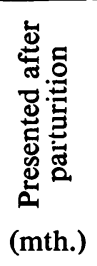 } & \multirow{2}{*}{ 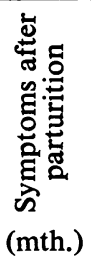 } & \multirow{2}{*}{ 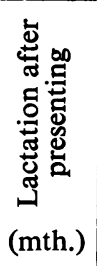 } & \multicolumn{3}{|c|}{ Hypertrophy } & \multirow{2}{*}{ 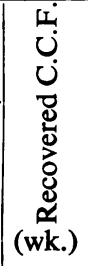 } & \multirow{2}{*}{ 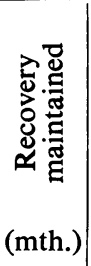 } & \multirow[b]{2}{*}{ 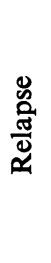 } & \multirow{2}{*}{ 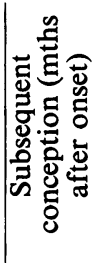 } & \multirow{2}{*}{ 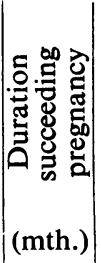 } & \multirow{2}{*}{ 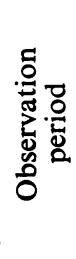 } \\
\hline & & & & & & $(\mathrm{mm})$. & $\begin{array}{c}T \\
\text { wave } \\
\text { inver- } \\
\text { sion } \\
(\mathrm{LV})\end{array}$ & $\underset{\text { cal }}{\text { Clini- }}$ & & & & & & \\
\hline $\begin{array}{l}13 \\
14 \\
15 \\
16 \\
17 \\
18\end{array}$ & $\begin{array}{l}28 \\
17 \\
35 \\
30 \\
40 \\
41\end{array}$ & $\begin{array}{r}5 \\
1 \\
8 \\
8 \\
7 \\
14\end{array}$ & $\begin{array}{l}4 \\
1 \\
3 \\
4 \\
5\end{array}$ & $\begin{array}{c}2 \frac{1}{4} \\
3 \frac{1}{2} \\
0 \\
2^{\frac{1}{2}} \\
-2\end{array}$ & $\begin{array}{c}9 \frac{1}{2} \\
10 \\
8 \\
2 \frac{1}{2} \\
0 \\
0\end{array}$ & & $\begin{array}{l}+ \\
+ \\
+ \\
+\end{array}$ & $\begin{array}{l}+ \\
+ \\
+ \\
+ \\
+ \\
+\end{array}$ & $\begin{array}{l}1 \\
2 \\
2 \\
1 \\
1\end{array}$ & $\begin{array}{c}9 \\
10 \\
1 \\
1 \frac{1}{2} \\
10 \\
12\end{array}$ & $\frac{2 \dagger}{+}+$ & $\begin{array}{l}\overline{8 \frac{1}{2}} \\
\overline{\overline{15}}\end{array}$ & $\begin{array}{l}\overline{1_{2}^{1}} \\
\bar{Z} \\
\overline{2 \frac{1}{2}} \dagger\end{array}$ & $\begin{array}{c}9 \frac{1}{2} \\
10 \\
8 \\
4 \\
10 \\
14\end{array}$ \\
\hline
\end{tabular}

** Spontaneous abortion.

$\dagger$ Hysterotomy following C.C.F.

* Two months after the follow-up was completed this patient had a normal confinement, and two months after that she had a recurrence of heart failure. 
(2) Persistent Cardiomegaly with Survival -6 confinements (Table VI). Six patients, followed over 4 to 14 months, had persistent cardiac enlargement with clinical evidence of hypertrophy, systolic murmurs, or gallop rhythm. Three of these suffered no symptoms during the nine months they were followed but the other three relapsed.

(3) Persistent Cardiomegaly and Fatal Outcome-5 confinements (Table VII). Two patients

TABLE VII

Episodes of Myocardial FaILURe ENDING IN DEATH

\begin{tabular}{|c|c|c|c|c|c|c|c|c|c|c|c|c|c|c|}
\hline \multirow{2}{*}{$\begin{array}{l}\text { Case } \\
\text { No. }\end{array}$} & \multirow{2}{*}{ Age } & \multirow{2}{*}{ Parity } & \multirow{2}{*}{ Twins } & \multirow{2}{*}{ 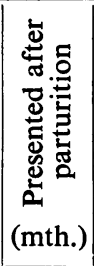 } & \multirow{2}{*}{ 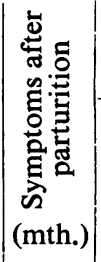 } & \multirow{2}{*}{$\begin{array}{c}\begin{array}{c}\text { Lactation } \\
\text { (mth.) }\end{array} \\
\begin{array}{c}\text { After } \\
\text { pre- } \\
\text { sent- } \\
\text { ing }\end{array}\end{array}$} & \multicolumn{3}{|c|}{ Hypertrophy } & \multirow{2}{*}{ 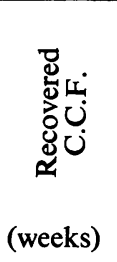 } & \multirow{2}{*}{ 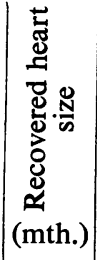 } & \multirow{2}{*}{ 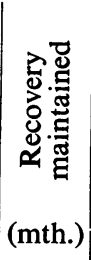 } & \multirow{2}{*}{ 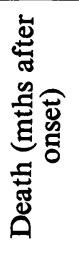 } & \multirow{2}{*}{ 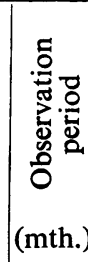 } \\
\hline & & & & & & & $\begin{array}{l}\text { QRS } \\
(\mathrm{mm} .)\end{array}$ & $\begin{array}{c}\mathrm{T} \\
\text { wave } \\
\text { inver- } \\
\text { sion }\end{array}$ & $\underset{\text { cal }}{\text { Clini- }}$ & & & & & \\
\hline $\begin{array}{l}19^{*} \\
20 \\
21 \\
22 \\
23\end{array}$ & $\begin{array}{l}34 \\
38 \\
26 \\
28 \\
38\end{array}$ & $\begin{array}{r}11 \\
4 \\
4 \\
5 \\
8\end{array}$ & + & $\begin{array}{l}1 \frac{1}{2} \\
3 \\
3 \\
2 \\
3\end{array}$ & $\begin{array}{l}1 \\
\frac{1}{4} \\
2 \frac{1}{2} \\
1 \\
2\end{array}$ & $\begin{array}{l}6 \\
5 \\
5 \\
1 \\
4\end{array}$ & $\begin{array}{lll}\text { RV4 } & 30 \\
\text { RV55 } & 26 \\
\text { RV6 } & 23 \\
\text { RV6 } & 29 \\
\text { SV1 } & 32\end{array}$ & $\begin{array}{l}+ \\
+ \\
+ \\
+ \\
+\end{array}$ & $\begin{array}{l}+ \\
+ \\
+ \\
+ \\
+\end{array}$ & $\begin{array}{l}\overline{-} \\
\overline{1} \\
2 \\
1\end{array}$ & $\begin{array}{l}\text { Z } \\
\text { I }\end{array}$ & $\begin{array}{l}\overline{7} \\
6 \frac{3}{4} \\
3 \\
3\end{array}$ & $\begin{array}{c}6 \\
8 \\
7 \frac{1}{2} \\
4 \frac{1}{2} \\
10\end{array}$ & $\begin{array}{l}6 \\
5 \\
7 \\
3 \frac{1}{2} \\
9\end{array}$ \\
\hline
\end{tabular}

* Same patient as Case 12, Table V.

died suddenly some months after making a satisfactory response, one of them in acute pulmonary œdema. A third who had also recovered from heart failure deteriorated and died after a fluctuating course. A fourth patient recovered completely from an episode which followed the delivery of stillborn twins, but after her next pregnancy she had a fatal recurrence. Heart failure in the fifth patient, which followed a twin confinement, also did not respond to treatment and she died five months after the onset.

\section{PROGNOSIS}

Subsequent Pregnancies. Only two of our patients have had full-term pregnancies during the follow-up. One woman (aged 22 years, parity 3 ) had two more children whom she fed at the breast, and she maintained normal health. A second (aged 33, parity 10) who had her first episode after being delivered of stillborn twins, died in heart failure after her next child. In both these patients the fresh conception coincided with a complete recovery which was maintained throughout pregnancy.

In addition there were three spontaneous abortions between 6 and 22 weeks gestation, and two hysterotomies with sterilization at 10 weeks. There was no recurrence, despite cardiomegaly or hypertrophy, in these five cases. One patient (aged 41, parity 14) relapsed when she was 4-6 weeks pregnant but she had had persistent cardiomegaly. This accords with the relationship of myocardial failure to the last trimester of pregnancy or the post-partum period and all our evidence suggests that early pregnancy does not precipitate failure. With succeeding full-term pregnancies, however, heart failure may or may not recur.

Age and Parity. In 13 cases in which recovery occurred without relapse, the average age was 28 years and the average parity between four and five. In the remaining 10 in whom there was a relapse or death, the average age was 33 years, and the average parity seven. (One of them was a patient with a second episode; she is included in the first group also for her first episode.) The differences in age and parity are significant $(P$ between 0.01 and 0.02 , and between 0.02 and 0.03 respectively). The separate effects of age and parity cannot be distinguished.

Lactation. The three primiparæ all recovered in spite of prolonged breast feeding. They will have been protected, to some extent, by youth and low parity. In 20 confinements among the 19 
multiparous women 11 suckled their babies for one month or less after presenting in failure; 9 suckled for longer. Only three of the eleven patients with short periods of breast-feeding suffered relapses or died, as against six of the nine with long periods. Lactation was stopped for therapeutic reasons in only three patients. Bias in the length of follow-up does not account for these findings.

Time of Onset and Medical Care. Complete recovery ensued in the four patients who presented in late pregnancy or within the first two weeks of the puerperium. Time of presentation therefore appears to be a significant factor in prognosis. Three other patients gave a history of onset of symptoms during this early phase; however, in these 3 there was an average delay of four months between onset of symptoms and presentation, in contrast with the remaining 20 cases where the average delay was only about three weeks. Two have had persistent cardiomegaly and one died after a refractory course. Thus, early onset alone did not appear to be associated with any consistent course, but early onset followed by prompt medical attention seemed to indicate a good prognosis.

Treatment. Bed rest, salt-restriction, diuretics, and digitalis relieved the symptoms of the woman in congestive failure. This was not the experience of some previous authors. Relapse or deterioration, however, sometimes occurred despite continued treatment. Recoveries at home with unchanged household routines and diets argued against the effects of diet or of activity after lying-in as principal factors in the course of the disease.

\section{Pathology}

Our necropsy material is limited to three cases, one of which we exclude because of tardy examination although the findings were much the same as in the other two. The heart of Case 22 weighed $370 \mathrm{~g}$. and showed left ventricular hypertrophy with dilatation of both ventricles. Fibrosis extended 6-10 $\mathrm{mm}$. into the myocardium beneath the numerous thrombi attached to the endocardium. The valves and coronary arteries were healthy. Microscopy showed hypertrophy and some perivascular fibrosis of the heart muscle. In the endocardium it revealed old and recent hæmorrhage and infiltration by chronic inflammatory cells; the endocardium was much thickened by fibrous or vascular and œdematous connective tissue (Dr. B. A. Bradlow).

Case 4 died of virus hepatitis two months after clinical and radiological recovery during which there were no signs of relapse. Yet at necropsy the heart was still enlarged with dilatation and hypertrophy of both ventricles (weight $370 \mathrm{~g}$.; left ventricular wall, $21 \mathrm{~mm}$.; right ventricular wall, $6 \mathrm{~mm}$.). The myocardium was otherwise normal microscopically, as were the endocardium, valves, and coronary arteries. The only histological abnormality was hypertrophy of the muscle fibres (Dr. R. Dando).

\section{DiscUSSION}

Course, Prognosis, and Treatment. The clinical picture is that of congestive failure. Recovery from heart failure is usually rapid. Our evidence suggests that if there is no ventricular hypertrophy, which was the case in three patients with early onset, the condition is rapidly reversible. If there is hypertrophy, recovery is more gradual; while if cardiomegaly persists, the prognosis is serious. In the only comparable follow-up, Meadows (1957) described five patients with persistent cardiomegaly, all of whom eventually became chronic cardiac invalids and died, although four had symptomatic remissions lasting 9 to 28 months.

Death may occur in an acute episode after symptomatic recovery, or more usually, after a fluctuating but intractable course. Five deaths occurred among Meadows' 15 patients. The higher mortality than in our survey could be accounted for by the longer period of observation, which in his series was less than five years in only one instance. High age and parity are associated with a poor outlook, and breast-feeding continued after the onset probably has an adverse effect. If subsequent pregnancies are allowed to proceed to term there is recurrence of the disease in about half the cases. Thus Meadows reported 8 maternities in recovered cases, half of which were followed by recurrences.

Heart failure in our patients responded to the usual measures. In patients with early onset, prompt $\mathbf{E}$ 
medical attention was associated with a good prognosis. To relieve failure we therefore used routine treatment, and even prolonged it in the hope of hastening and maintaining recovery. We would interrupt lactation (although this sets a special problem in a community where artificially fed infants often die in the first years of life), and we sought to prevent or terminate subsequent pregnancies even in young women. Sterilization should be considered in older women of high parity.

Pathology. Necropsies in three patients revealed cardiac enlargement due to hypertrophy and dilatation. Jensen (1938) described one similar case, but most of the 16 North American necropsy reports emphasized dilatation rather than hypertrophy, with weights of 260 to $650 \mathrm{~g}$., a flabby myocardium, antemortem thrombi in the chambers of the heart, and some degree of endomyocardial fibrosis. Microscopic changes were most obvious in the endomyocardium underlying mural thrombi, but other authors mention focal or diffuse necrosis of muscle fibres with hæmorrhages and moderate infiltration of lymphocytes and macrophages. One necropsy in South America was similar to these, but in a second Chagas' disease, and in a third miliary tuberculosis was found in the myocardium (Benchimol et al., 1959).

AEtiology. There are two views of the ætiology of this condition. The first is that peri-partum heart failure is a disease in itself. In favour of this view it is argued that because particular groups of women are susceptible, they are likely to be affected by a particular environmental or constitutional factor, and therefore by a specific condition. Thus women who are negroid and living in poor conditions or who are of high age and parity or delivered of twins are especially vulnerable. Further support for the concept of a specific disease is given by the regular clinical pattern which includes the time of onset, the idiopathic cardiomyopathy in otherwise healthy women, the complete recovery in many cases, and the recurrences induced by subsequent pregnancy.

The other view is that peri-partum heart failure is due to physiological stress occurring in all confinements, but affecting only hearts pre-disposed to failure from whatever cause. The following arguments are put forward in favour of this concept.

First, a number of cases have been reported in which there were possible pre-disposing causes (Freeman, 1947; Bashour and Winchell, 1954; Silber and Saphir, 1957; Benchimol et al., 1959) and it is well known that rheumatic hearts may fail in the first few days of the puerperium. It therefore appears possible that in a number of heart diseases childbearing may precipitate failure in the peri-partum period.

Secondly, there are divergences between previous series and our own, and also within our series of cases. Ventricular hypertrophy was a clinical feature in most of our patients but has hardly been remarked previously; at necropsy the flabby myocardium and degenerative changes as described in some American cases were not seen. Within our own series also we have been able to differentiate groups by the clinical course, by the occurrence of ventricular hypertrophy, and by the persistence of cardiomegaly.

Thirdly, our cases bear more resemblance to other types of idiopathic myocardial disease in Africans than may at first appear. Heart failure of uncertain cause is common in Africans in South Africa (Gillanders, 1951; Altman and Stein, 1956; Grusin, 1957; Schwartz et al., 1958). Rapidly reversible myocardial failure in men has been described by Grusin (1957). Three patients with hypokinetic circulations seemed distinct from the remaining thirteen with hyperkinetic circulations and probable beri-beri. These three patients may correspond to our group without cardiac hypertrophy who made rapid recoveries. The more common cardiomyopathy described as "nutritional" heart disease (Gillanders, 1951) has features similar to our group with persistent cardiomegaly and relapsing course. Incidence increases with age and the necropsy findings are similar to those reported in our cases of peri-partum failure. Thus peri-partum myocardial failure resembles the Gillanders syndrome in its age incidence, in its distribution among negroes living in poor social conditions and, when cardiomegaly persists, in its clinical features and course.

There remain those patients with ventricular hypertrophy and peri-partum failure who made a complete recovery. Other cardiomyopathies seldom recover. Yet if in our cases the strains of maternity precipitate failure, we may assume that recession of these strains promotes recovery, even in diseased hearts. It may also be that some cases of idiopathic myocardial failure in Africans do regress, since we know of no follow-up rigorous enough to rule this out. We might therefore postulate that peri-partum stress precipitates failure in cases of idiopathic heart disease that are in the process of development. If this is so, we would expect that where peri-partum failure is found, idiopathic disorders of heart muscle will be found in the general population. This occurs in Johannesburg. Yet among the negroes of New Orleans, where peri-partum failure is common, other idiopathic heart disorders are said to be uncommon (Hull, 1959). The concurrence between peri-partum failure and idiopathic heart disease in Johannesburg may thus be incidental and the question remains open.

Whatever the cause of peri-partum heart failure, its occurrence among caucusoids and negroids excludes 
an entirely racial origin. The concentration of cases amongst negroes living in poor social conditions and in particular cities, and the declining prevalence over the last 20 years in the Charity Hospital, New Orleans (Hull, 1959) points to some environmental factor such as the delayed effect of early malnutrition. Incidence and prognosis are connected with age, parity, and lactation; this combination is likely to be related to physiological stress. In peri-partum heart failure the onset is later than the phase of greatest hæmodynamic load, and in most cases later also than the post-partum accession of blood-volume. We might therefore look to metabolic changes, such as the abrupt change from anabolism to katabolism following parturition Macy and Hunscher, 1934; Hunscher et al., 1935; Hummel et al., 1936).

\section{SUMMARY}

For the first time in Africa, peri-partum myocardial failure is described. The follow-up here reported comprises 23 episodes in 22 African women in Johannesburg.

The time relations of the onset of failure and maternity, specifically in the last trimester of pregnancy and in the post-partum period, are established. The condition is seen to be by far the commonest type of idiopathic myocardial failure in Johannesburg in African women before the menopause.

A significant relationship is shown between incidence on the one hand and high parity, high childbearing age, and twinning on the other.

An unfavourable prognosis is significantly related to high age and parity; long-continued lactation after presentation and subsequent pregnancies are also seen to have adverse effects. Early onset followed by prompt medical attention is associated with a favourable outcome.

The cases are placed in three groups according to the presence or absence of ventricular hypertrophy and the persistence of an enlarged heart. These groupings have a relationship to prognosis.

The definition of the syndrome is discussed, and previous reports are reviewed. Similarities and divergences are noted between our series and earlier ones, and also between our series and other idiopathic cardiomyopathies among Africans. Alternative hypotheses as to ætiology are formulated.

We thank Dr. V. H. Wilson for his encouragement, Dr. Geoffrey Wade for much helpful criticism, Dr. Wallace Brigden for his comments on the paper, and Dr. I. Frack for permission to publish this material. Dr. Zena Stein assisted with the statistical analysis and made many thoughtful contributions. We acknowledge Dr. Michael Hawthorn's contribution in establishing the Alexandra Health Centre Cardiac Clinic.

\section{REFERENCES}

Altman, H., and Stein, H. (1956). Brit. med. J., 1, 1207.

Bashour, F., and Winchell, P. (1954). Ann. intern. Med., 40, 803.

Benchimol, A. B., Carneira, R. D., and Schlesinger, P. (1959). Brit. Heart J., 21, 89.

Brigden, W. (1957). Lancet, 2, 1179, 1243.

Chang, T. H. (1952). Chinese med. J., 70, 227.

Freeman, A. M. (1947). J. med. Ass. Ala., 17, 163.

Gampel, B. (1959). Personal communication.

Gillanders, A. D. (1951). Brit. Heart J., 13, 177.

Gillman, J., and Gillman, T. (1951). Perspectives in Human Malnutrition. Grune and Stratton, New York.

Gouley, B. A., MacMillan, T. M., and Bellet, S. (1937). Amer. J. med. Sci., 199, 185.

Grusin, H. (1957). Circulation, 16, 27.

Hayward, G. W., and Weitzman, D. (1958). Brit. Heart J., 20, 590.

Hull, E. (1959). Personal communication.

$\longrightarrow$, and Hafkesbring, E. (1937). Med. Surg. J., 89, 550.

, and Hidden, E. (1938). Sth. Med. J. Nashville, 31, 265.

Hummel, F. C., Sternberger, H. R., Hunscher, H. A., and Macy, I. G. (1936). J. Nutrit., 11, 235.

Hunscher, H. A., Hummel, F. C., Erickson, B. N., and Macey, I. G. (1935). J. Nutrit., 10, 579.

Jensen, J. (1938). The Heart in Pregnancy., p. 324. Henry Kimpton, London.

Levine, S. A. (1958). Clinical Heart Disease, 5th edition. W. B. Saunders, Philadelphia and London.

Lindeboom, G. A. (1950). Ned. Tijdschr. Geneesk., 94, 2453.

Macy, I. G., and Hunscher, H. A. (1934). Amer. J. Obstet. Gynec., 27, 878.

Marcus, N. L. (1955). J. Florida med. Ass., 41, 938.

MacKinnon, H. H., and MacKeen, R. A. H. (1949). Canad. med. Ass. J., 61, 308.

Meadows, W. R. (1957). Circulation, 15, 903.

Melvin, J. P. Jr. (1947). Ann. intern. Med., 27, 596. 
Musser, J. H., Sodeman, W. A., and Turner, R. H. (1938). Ann. intern. Med., $12,739$.

Porak, C. (1880). De l'influence reciproque de la grossesse et des maladies du coeur. Thesis, Paris.

Rosen, S. M. (1959). Brit. med. J., 2, 5.

Schwartz, M. B., Schamroth, L., and Seftel, H. C. (1958). Med. Proc., 4, 275-81.

Seligman, C. G. (1957). Races of Africa. Oxford University Press.

Silber, E. N., and Saphir, O. (1957). Practice of Medicine, ed. L. H. Sloan, Vol. 6, 233. Hagerstown, Maryland, W. F. Prior Company.

Susser, M. W., and Stein Z. A. (1958). J. Obstet. Gynac. Brit. Emp., 65, 769.

Vaquez, H., and Millet, M. (1898). Du Coeur dans la Grossesse Normale. La Presse médicale, 1, 61.

Vilter, R. W., and McKee, E. E. (1943). Ohio St. med. J., 39, 142.

Virchow, R. (1872). Beitr. Z. Gynak. Geburtsh. herausgeg. Ges. Gebursh. Berlin.

Von Bonsdorff, B. (1939). Acta med. Scand., 100, 390.

Wood, P. H. (1956). Diseases of the Heart and Circulation. 2nd ed. Eyre and Spottiswoode, London.

Woolford, R. M. (1952). Ohio St. med. J., 48, 924. 